\title{
Law-Making as a Strategy for Change: Indonesia's New Village Law
}

\author{
Jacqueline VEL* \\ Van Vollenhoven Institute, Leiden Law School, Leiden University; Royal Netherlands Institute of \\ Southeast Asian and Caribbean Studies (KITLV), Leiden
}

Yando ZAKARIA**

Circle for Rural and Agrarian Reform (KARSA), Yogyakarta

Adriaan BEDNER ***

Van Vollenhoven Institute, Leiden Law School, Leiden University

\begin{abstract}
In 2014, the Indonesian president signed a new Village Law (no. 6/2014). This statute started a new phase in the ongoing history of village governance policy, moving the village from a position as an administrative unit in a top-down system towards one of an autonomous community. The present article analyses how distinct "policy communities" in Indonesia started a process that helped shape the 2014 Village Law in order to promote their long-term political agendas, how their involvement was facilitated by the particular features of Indonesia's law-making process, and how they managed to get a Bill passed that went against considerable vested interest from government bureaucracies. However, they have been less successful in securing implementation of the new law, as this process is still dominated by the government bureaucracies that were "defeated" in the law-making process.
\end{abstract}

Keywords: law-making, vernacularization, ecentralization, Village Law, Indonesia

\section{INTRODUCTION}

Decentralization does not happen overnight. It is a long process, characterized by political contestation and dotted with legal landmarks in a broad range of fields. A case in point is the decentralization process in Indonesia following the resignation of President Suharto in

\footnotetext{
* Senior researcher at the Van Vollenhoven Institute, Leiden Law School, Leiden University and at the Royal Netherlands Institute of Southeast Asian and Caribbean Studies (KITLV) in Leiden. Correspondence to Jacqueline Vel, Van Vollenhoven Institute, Steenschuur 25, 2311 ES Leiden, The Netherlands. E-mail address: j.a.c.vel@law.leidenuniv.nl.

** Independent researcher at the Circle for Rural and Agrarian Reform (KARSA) in Yogyakarta, Indonesia. A first draft of this paper was presented at the international workshop "New Law, New Villages? Changing Rural Indonesia" in May 2016 in Leiden, organized by KITLV, Van Vollenhoven Institute, and the Norwegian Centre for Human Rights Research of the University of Oslo. The authors are very grateful to Gerry van Klinken and Ward Berenschot who made comments to earlier drafts, and two anonymous reviewers for their insightful comments. A considerable part of the research for this paper was conducted with the aid of a KITLV fellowship (Y.Z.) and by the programme "Governance Markets and Citizens in Indonesia” funded by the Royal Netherlands Academy of Arts and Sciences (J.V.).

*** KITLV Professor of Law and Society in Indonesia at the Van Vollenhoven Institute, Leiden Law School, Leiden University, The Netherlands.
} 
May 1998, which was closely linked to the simultaneous trajectory of democratization. ${ }^{1}$ The major statutory landmarks of this decentralization have been the Regional Autonomy Laws no. 22 and no. 25 of 1999, the Second and Third Amendments to the Constitution (2000 and 2001), and the Law on Regional Government no. 32 of 2004. The 1999 laws devolved authority to the regions ${ }^{2}$ and introduced democratic controls, the constitutional Amendment anchored this change in the Constitution and constituted the democratic representation of the regions at the national level, and the 2004 law introduced direct elections of regional government heads. There is a huge literature on these decentralization laws-how they came into being and what their effects have been. ${ }^{3}$ However, this does not yet apply to the latest addition to the series of decentralization laws: the 2014 Village Law (no. 6/2014).

The genesis of this law differs profoundly from its predecessors in that it was not imposed in a top-down fashion, but the result of a participatory law-making process. The Village Law is revolutionary in its scope, pushing decentralization to the level of Indonesia's nearly 75,000 villages: the village no longer is just the lowest level of government administration, but instead is recognized as an autonomous legal subject with its own authorities and rights. ${ }^{4}$ The new Village Law entitles villages to receive considerable cash transfers from the national and district government which they can use according to their own views. The amount of these "village funds" is specified as $10 \%$ of the budget transfers from the national government to the districts, in addition to the direct transfer of a similar sum (Article 72 and its Elucidation). With these funds, even the poorest villages now have a budget that they can spend on the public projects they prioritize themselves.

This article addresses the question of how it has been possible that such a revolutionary law, which goes against so many vested interests at higher levels in the state hierarchy, has been adopted by government and Parliament. We will argue that this happened because of three factors: convergence of several distinct policy goals in the proposed Bill at a favourable moment in Indonesia's political history, the collaboration between the policy communities that campaigned for these goals, and the opening-up of the political system for participatory forms law-making after 1998. We use the term "policy communities" as an analytical concept to catch the variety of actors that participated in the law-making process. ${ }^{5}$ Policy communities comprise people who share a social or political objective. They are not necessarily colleagues or members of the same organization; what unites them is the shared policy goal. Within a policy community, there is a consensus about the definition and analysis of particular problems, and how these should be resolved. In other words, within a policy community, one finds relatively stable dialogues and a degree of consensus about policy theories. ${ }^{6}$ Below, in the section about making the Village Law, we will further elaborate on this concept.

In addition, the analysis of the making of the 2014 Village Law sheds light on several important characteristics of the law-making process in Indonesia more generally. The first is

\footnotetext{
1. Schulte Nordholt \& van Klinken (2007), p. 15.

2. When we use the word "region," we refer to both the province and the district.

3. See Schulte Nordholt \& van Klinken, supra note 1; Holtzappel \& Ramstedt (2009); Hadiz (2004), pp. 697-718; Erb et al. (2013).

4. Eko (2014)

5. Veerman (2015)

6. Bagchus (1996); Veerman \& Hendriks-de Lange (2009).
} 
that participatory law-making processes have a high probability of resulting in a "negative" symbol act: a law that serves to express particular values in the political sphere rather than to enforce particular norms of behaviour and the objectives lying at their basis. ${ }^{7}$ When several policy communities are involved, each with their own objective, the chance for such "negative" compromises is considerable. The typical Indonesian version of this result is a framework law, which lacks substantive rules but combines a set of lofty, broad principles with a legislative agenda. As a result, political contestation will shift to the implementation phase. ${ }^{8}$ A good example of such a law is the Company Law (no. 20/2007): it includes a provision on compulsory corporate social responsibility (CSR) for resources companies, but, as Rosser and Edwin have argued, its implementation remains dependent on political leadership that supports a mandatory approach to CSR and that is willing to act on this issue, against the interests of multinational corporations and large domestic conglomerates. ${ }^{9}$

A second characteristic of the Indonesian law-making process is that few laws take sufficient account of local conditions, in particular, of local power structures, customary, or religious norms. ${ }^{10}$ In this respect, the Village Law is different, as it accommodates for regional variety and intends to address local power imbalances through provisions for strengthening village-level democratic institutions. ${ }^{11}$ This, we will argue, is largely the result of the efforts of one particular policy community that pursued this matter relentlessly from the start to the finish.

A third issue that will be highlighted by this case of making the Village Law is that the process of law-making takes place in a context where "practical norms" are governing the bureaucracy involved in this process. ${ }^{12}$ The concept of "practical norms" builds on earlier work in development administration by notably Riggs and has recently been further developed in comparative studies about public services and the local delivery of public goods in Africa. At its core is the attempt to understand how practices not complying with formal rules are nevertheless regulated. ${ }^{13}$

The article will proceed as follows. We will first address the background and context in which the need for this new law emerged, followed by an analysis of the particular conjuncture in 2005 that inspired the agenda for change of the major policy communities involved, and their goals and interests. Then we will explain the procedures for law-making that enabled policy communities to play such an influential role. The following section will elaborate the concept of policy communities, and provide an overview of their involvement in the Village Law process, from 2005 up to 2014. In the next section, we summarize the content of the new law, showing the result of compromise struck between all the interests involved and highlighting the issues that have surfaced during the implementation of the Village Law as from April 2015. In the conclusion, we discuss why (participation in) making a new law has had only limited effect on changing pre-existing dynamics of power to arrive at new outcomes-at least so far.

7. Van Klink (2014), p. 8; Aubert (1967).

8. Good examples are the 1982 Environmental Law (Bedner (2008)); and the 2012 Food Law (Vel et al. (2016)).

9. Rosser \& Edwin (2010), pp. 1-22.

10. The classical theoretical elaboration of this idea is Sally Falk Moore's semi-autonomous social field (Moore (1973)). For an overview, see the World Bank's World Development Report 2017 on Governance and the Law. See also Hesseling (2009), p. 243; Ubink et al. (2009); and, for a recent example in this Journal, Trzcinski \& Upham (2014), pp. 55-77.

11. Antlöv et al. (2016), pp. 161-83.

12. The classical work is Riggs (1964).

13. Olivier de Sardan (2011), pp. 22-31; Olivier de Sardan (2013), pp. 43-64. 


\section{THE CONTEXT OF CHANGING VILLAGE GOVERNANCE LEGISLATION}

In order to explain the rise of a movement for creating a new Village Law in the early 2000s, we first need to understand the historical context of village government in Indonesia and the arguments in favour of and against village autonomy. These arguments go back to the colonial era, were rephrased in the nationalist policies after Independence, and led to continuous debates under the centralized policies of the authoritarian regime of President Suharto (1965-98). The national government's interest in village governance revolves around the embedding of the village in hierarchical schemes: What is the relation of the village with the national state? How can the village serve the administrative needs of higher levels of government? The main issues at the village level also concern power and authority: Who should be entitled to decide about the use of village land and assets? What should be the procedure for deciding who will be village head, and what should be his or her powers? How can the interests of common villagers be served and protected, and what are the criteria for in- or exclusion of inhabitants into a village community? These questions have been answered differently in successive periods of Indonesia's political history.

\subsection{From Autonomy to Subordination, and Unification or Diversity}

During the late colonial era, the central colonial government disposed of only a very limited government apparatus. It adopted the pragmatic policy of allowing villages to govern their internal affairs according to their customary (adat) law, and implicitly provided legal recognition of adat institutions within the village boundaries. The village head had a dual role: he served as the head of the community and the representative of the colonial government at the same time. This dual structure facilitated the extractive policies of levying taxes and forcing or promoting the cultivation of products for the global market. Village heads themselves held a financial stake in tax collection, which easily led to abuse. At the same time, part of the tax rewards were used for financing health care for villagers and the promotion of similar public goods. ${ }^{14}$

The first Indonesian Constitution, of 1945, was a sharp ideological rejection of the colonial system. ${ }^{15}$ A spirit of nationalism and national unity that pervaded the document discouraged village autonomy and diversity. Nonetheless, the Constitution did offer some provision for diversity in local government through its Article 18, which referred to "the government system and the right of origin (hak asal-usul) of special territories (daerah-daerah yang bersifat istimewa)." The Elucidation to this article added that the special status of self-governing entities (zelfbesturende landschappen) and "people's communities" (volksgemeenschappen) was to be respected (dihormati). This included respect for their customary rights. ${ }^{16}$ The Constitutions of 1949 and 1950 held comparable clauses. ${ }^{17}$

At the legislative level, the period between 1945 and 1965 saw a rapid succession of laws regulating village governance-six laws within a period of just 20 years. Their overall trend

14. Breman (1982), pp. 189-240.

15. As rightly pointed out by an anonymous reviewer of this article, the 1945 Constitution did provide for the continuation of all Dutch colonial law until expressly overturned.

16. Bedner \& van Huis (2008), p. 171.

17. Arts 64 and 65, viz. 131 and 132 . 
was towards a unified system for village governance for the whole country in combination with a large degree of village autonomy. This trend was reversed by Suharto's New Order regime, which held that village-level autonomy went against the national interest of stimulating economic growth, stability, and security. ${ }^{18}$

The New Order introduced major changes in village governance that reinforced the power of the central government. Village heads were no longer elected by the village population, but selected and appointed by the district head. Many of these new village heads came from outside the village, had a military background, and were faithful political clients of the new regime. Autonomy was further limited by Law no. 3/1975, which put severe restrictions on political activity. Parties were still allowed to organize at the district level, but not in the villages. Lack of control by village institutions facilitated abuse of power by village heads and the implementation of the land-reform programme introduced in $1960^{19}$ was put on hold indefinitely, land policy changing towards facilitating commercial use of land. ${ }^{20}$ Decrees no. 6/1972 and no. 15/1975 of the Minister of Agrarian Affairs opened possibilities for land acquisition in customary land areas in exchange for a compensation. While officially it concerned a voluntary procedure, in practice, such acquisition was often forced by the government and the military. ${ }^{21}$ The village head's authority to grant permission for such land acquisition became an important tool for corruption. ${ }^{22}$

In 1969, President Suharto issued Decree no. 16/1969 about village funds (dana desa), an annual central government grant for all villages in the country, which was allocated to the districts rather than directly to the villages. The size of the grant depended on the number of villages in a district. This was a financial stimulus for unification of local governance in "national style desa," which led to the fragmentation of even the famous and socioculturally entrenched nagari in West Sumatra. ${ }^{23}$ These developments towards national uniformity and centralized control culminated in Law no. 5/1979 on Village Government. That statute defined the desa as an administrative unit under the co-ordination of the subdistrict head (camat) and had as its official objective to support national economic growth, equality, stability, and security. It created new institutions under firm control of the village head to provide implementation capacity for the national government's policies. By ignoring adat institutions, the law further undermined customary claims to land. Development was organized in the form of projects, which became the currency in the clientelistic system that through a long chain connected village heads to the president. These government policies were supported by severe repression of any opposition. ${ }^{24}$

\subsection{The Agenda for Change}

Soon after the demise of the New Order regime in 1998, the 1979 Village Law was replaced by the new regional autonomy legislation (Laws no. 22 and no. 25/1999). Districts and

\footnotetext{
18. Soemarno et al. (1980).

19. Based on the Basic Agrarian Law no. 5/1960, Arts 7, 10, 17, 53, and Law no. 56/1960, GRs no. 224/1961 and no. $41 / 1964$.

20. Lucas \& Warren (2013).

21. Bedner (2001), pp. 155-6.

22. Soepomo (1993).

23. Von Benda Beckmann \& Von Benda-Beckmann (2013), p. 130.

24. Lucas \& Warren, supra note 20.
} 
villages were no longer solely administrative units in a hierarchical chain, but regained a large degree of autonomy. Nonetheless, to the activists who had been struggling for more autonomy for villages and to those who saw the new autonomy as a means of promoting land rights for indigenous people, the first piece of implementing legislation specifically concerned with villages was disappointing. Government Regulation (GR, Peraturan Pemerintah) no. 72/2005 merely addressed issues of village government organization and provided hardly any instruments for implementing rights or policies.

One of the main issues concerned finances. Between 1999 and 2005, the budget for village-level programmes increased considerably, but villages could only decide about the allocation of a small part of it. GR no. 72/2005 widened the opportunities for villages to obtain control over these funds, but in a neoliberal, non-egalitarian fashion: village governments had to submit project proposals and lobby for their funding in competition with other villages. The population thus became dependent on their village head and his or her skills in winning projects, and, while some villages obtained, many others got no projects at all. ${ }^{25}$

On top of this, villagers themselves were hardly involved in evaluating whether in the end these projects were beneficial to them. One of the sources of funding of these competitive projects was the PNPM Mandiri, a programme adopted from an earlier World Bank scheme (the Kecamatan Development Programme), whose rules and procedures led to the prioritization of projects concerning infrastructure and micro-credit. Their success was measured based on material and physical indicators-not on what the local population thought of them. ${ }^{26}$

The criticism on GR no. 72/2005 can be read as the agenda for change that eventually resulted in the 2014 Village Law. The first thing missing was acknowledgement of the diversity of community life in rural Indonesia. A national law ought to create the necessary framework in which a wide variety of local institutions and governance styles can function. Second, the autonomy granted to villages was limited to "leftovers"- what remained once the district government had implemented all of its policies. Villages thus had no autonomy in managing the public projects that aimed to support them. Third, most of these programmes and projects were designed, decided, and implemented without any direct involvement of the villages themselves. And, fourth, there was a gap between programmes at the village-level and supra-village-level development activities. These four arguments together provided the basis for a process of legal mobilization.

\section{PARTICIPATION IN LAW-MAKING IN INDONESIA}

Just as the desa has moved back and forth between subordination and autonomy, so has the law-making process in Indonesia oscillated between a top-down model—dominated by the government — and an open one, in which Parliament plays a considerable role and civil society can participate. ${ }^{27}$ After the start of Reformasi in 1998 , civil society

25. Aspinall \& Sukmajati (2016).

26. AKATIGA (2010); Datta et al. (2011); Gibson \& Woolcock (2005); McCarthy et al. (2014); Soehendra (2010); Voss (2008).

27. At present, it is legally impossible for Parliament to truly dominate law-making, because the president can block any act initiated by Parliament (Art. 20(3), Constitution). 
organizations (CSOs) found new ways to exercise influence on law-making. This was demonstrated most visibly in the preparation of the Bill on Natural Resources-a process that ran from 2000 until 2003 but was eventually aborted by the government. ${ }^{28}$ Yet, despite this initial lack of success, different forms of participation in law-making continued, facilitated by a new law on law-making (no. 10/2004). Article 53 (now Article 96 of Law no. 12/2011) stated that "society has the right to give input in preparing or discussing a draft law." This provision has been translated into a range of opportunities for stakeholders to influence the law-making process.

\subsection{Options for Participating in Law-Making}

The first option is in getting an item on the legislative agenda, the so-called Program Legislasi Nasional (the National Programme for Legislation or Prolegnas). The Prolegnas is determined by the president and Parliament together at the start of the five-year term of a newly elected Parliament and is adapted before each year's session (Article 20, Law no. 12/2011). If a civil society organization wishes to promote a certain law, it first needs to convince the Parliament and the president that they should include it into the Prolegnas. $^{29}$ Only then does it make sense for them to start lobbying for the actual changes they wish to effect. ${ }^{30}$ One should be aware that inclusion in the Prolegnas is by no means a guarantee that a law will come into being though: the highest rate of Prolegnas Bills realized was 56 out of 76 in 2009, while, in 2013, the rate had dropped to 24 out of $70 .{ }^{31}$ Still, Prolegnas is the preliminary hurdle to be tackled.

The first step in the actual law-making process is the creation of the so-called "Academic Document" (Naskah Akademik), a report setting out the parameters of the law and the problems that it seeks to resolve. It is required for every new Bill (Article 43(3), Law no. 12/2011). The Academic Document offers a potentially effective avenue of exercising influence, but in practice this opportunity to determine the starting point for the ensuing debates is seldom used by the law-makers involved. Most academic documents in preparation of new laws are abstract and general, and they do not pay much attention to practical issues involved. ${ }^{32}$ However, there may be exceptions to this rule, as we will later see in the case of the Village Law.

A next opportunity for influencing the law-making occurs when a special drafting team is charged with preparing the Bill. It depends on whether the item in the Prolegnas was initiated by the government or by Parliament whether civil society actors can participate. ${ }^{33}$ Where it

28. Arnscheidt (2009).

29. Law no. 12/2011 provides a complex procedure for Parliament and the government to determine the Prolegnas, securing equal amounts of influence for both sides. The co-ordination between the efforts of Parliament and the government lies with the Parliamentary Body for Legislation (Art. 21(1)) and eventually the Prolegnas are established by parliamentary decision (Art. 22(2)). It is unclear whether in practice this allows Parliament to play a dominant role. Art. 22(1) also stipulates that there must be agreement (kesepakatan) between government and Parliament about the Prolegnas.

30. Art. 19(2) determines that the Prolegnas should include the background and goal of the law-making, the objective that it aims to achieve, and the planning and field of the regulation. According to Purawan (2014), pp. 534-45, in practice, these objectives and goals are so vague that they give hardly any guidance at all.

31. Purawan, supra note 30 , p. 540.

32. Anggono (2014).

33. The Representative Regional Council (Dewan Perwakilan Daerah) can also initiate a Bill, but this seldom happens, so we will leave aside this procedure. 
concerns a government Bill, the process is run by the department that holds authority over the policy field concerned, with a co-ordinating role for the Ministry of Justice and Human Rights (Article 47, Law no. 12/2011). Government drafting teams consist of representatives from other relevant departments, but they usually also include non-government experts. Having one's own expert included in this team offers a shortcut to influence, which is something most CSOs are well aware of. ${ }^{34}$ In case of a Parliament-initiated Bill, it often is easier for CSOs to exercise influence, because staff support for developing Parliament Bills is much more limited. ${ }^{35}$

The research available indicates that the drafting process in this phase is often highly contentious. This applies in particular to government Bills where more than one department is involved, or where a Bill may affect the interests of another department. The politics common to all bureaucracies is exceptionally strong in Indonesia, where it is known as "ego-sektoralism." 36 This means that a lot of bureaucratic infighting takes place before a Bill may proceed to the official stage of parliamentary debates.

This bureaucratic infighting may continue during the debates in Parliament. These are conducted mainly in a Special Committee (Panitia Khusus), where the major parties are represented to discuss the draft among themselves and with the relevant government department. The debates in the Special Committee are often quite contentious. Whether CSOs and others can influence them depends on their relations with MPs. In the case of the Village Law three academic activists were appointed as expert staff, which provided a unique opportunity for continued influence.

One of the results of this contentious character of law-making, which inevitably leads to compromises, is a tendency to keep laws relatively general and ambiguous. Although we do not argue that most of Indonesian laws are "negative symbol acts," they seldom provide a clear mechanism of implementation and leave contentious points to be resolved by implementing regulations. ${ }^{37}$ This has an important implication for CSOs and others involved in a policy community because, if they want to exercise genuine influence, their involvement cannot stop with the passing of the law. They need to make sure to remain involved in the drafting of implementing regulations as well as in the actual implementation itself.

\subsection{Methodology Note: An Insider's View}

Before we proceed with our analysis of the law-making process of the Village Law, we would first like to say a few things about the research method we used. One of the authors of this article (Zakaria) has participated actively in the process described in the previous Section 4.1. He has been involved in research and activism concerning a new village law since 2000 and he was one of the members of the expert team composed by the Parliament for drafting the new Village Law (2012-13). It provided him with access to all meetings

34. About this process, see also Datta et al. (2011).

35. Remarkably, the number of Parliament Bills has now outgrown the number of government Bills. For instance, from the 37 Bills prioritized in the Prolegnas in 2015, 26 were Parliament Bills, ten government Bills, and one a Regional Representative Council Bill (Taufiqurohman (2015)).

36. Bedner, supra note 8, pp. 171-98; McCarthy (2011).

37. Bedner, ibid.; Tømte (2016) explains that "implementing regulations refers to regulations, which in other countries are given names such as delegated legislation, subordinate legislation, secondary legislation, legislative instruments or statutory instruments." 
concerning the making of the Village Law, and access to documents and oral information provided to the expert committee in this period. He wrote many articles, reports, and books (in Indonesian) about this process and the ideas behind a new village law. ${ }^{38} \mathrm{He}$ is also a founder of KARSA, ${ }^{39}$ one of the organizations that actively lobbied for the new Village Law. Most of the information used in this article relies on his notes and experiences. The first author (Vel) has conducted interviews in 2015 with representatives of the main policy communities in campaigning for the Village Law. The results of these interviews have been used for making the overview in the next section. Together, the three authors have analyzed the information from the field and positioned the findings in larger debates on law-making and democratization, and how these contribute to understanding the legal system in Indonesia.

In the next sections, we will look at how policy communities dealt with the particular features of the Indonesian law-making system in the drafting and implementation of the new Village Law.

\section{POLICY COMMUNITIES' PARTICIPATION IN LAW-MAKING}

The key actors in our account are "policy communities." This is an analytical concept to catch the variety of actors who participate in a law-making process. ${ }^{40}$ It comprises individuals or groups, such as civil society actors, companies, government institutions, or officials, and donor organizations, who share a social or political objective translated into a policy goal. They are not necessarily colleagues or members of the same organization: what unites them is the shared policy goal. For the individuals and organizations collaborating as a policy community, the shared objective guides all their activities, of which the drafting of a law is just one part.

This distinguishes "policy communities" conceptually from "interest coalitions," as used for instance by Rosser and Edwin. ${ }^{41}$ These authors examined how various categories of actors collaborated in the making of the Company Law in Indonesia in 2005-07. The factor that either unified them or set them apart was their shared interest in having mandatory CSR regulated by the law, or their preference for avoiding such legal obligation and keeping CSR voluntary. The interests were defined in close relation to the choice between mandatory or voluntary CSR, and thus limited to a core element of this specific law. Policy communities, on the other hand, share a broader policy goal, not just a temporary interest, nor do they necessarily share a collective identity. ${ }^{42}$ The latter characteristic also distinguishes them from "social movements," which refers to networks of individuals, groups, and/or organizations, engaged in political or cultural conflicts, on the basis of shared collective identities. ${ }^{43}$

Many policy communities coalesce around general ideals or certain human rights that they seek to translate into national legislation and local programmes of action. In the case of the Village Law, it concerned norms on accountability, transparency, and participation, but also the right to public services for the fulfilment of basic human needs. These norms are meant to

38. Zakaria (2004), which is included in the list of references, is just one of these. He wrote the first draft of his contribution to this article during his research fellowship at KITLV in Leiden in 2015.

39. KARSA (Lingkar Pembaruan Desa dan Agraria) Circle for Agrarian and Village Innovation, Yogyakarta.

40. Wright (1988), pp. 593-612; Bagchus, supra note 6; Veerman \& Hendriks-de Lange, supra note 6.

41. Rosser \& Edwin, supra note 9.

42. Although this may be the case, as for instance in the case of the Indonesian Village Head Association.

43. Diani (1992), pp. 1-25. 
be grounded in local social and political realities. Most policy communities include persons who can act as intermediaries with the capacity of translating general ideals into forms that make sense in national and local situations through a process of vernacularization. ${ }^{44}$

The initial steps for such "idealist" policy communities in the law-making process include (1) translating a universal ideal into a campaign goal, (2) identifying and mobilizing allies and designing a legal-political strategy, and (3) getting access to and participating in the legal drafting process. Many analyses stop here, but in fact the role of policy communities extends beyond the promulgation of the law. However, most policy communities are better equipped for advocacy than for policy implementation and have difficulties in linking the formal law to practical settings.

\subsection{Policy Communities and the Village Law: Six Shared Goals}

How, then, did the process of making a new Village Law unfold and what was the role of policy communities in this process? From 2006 onwards, a number of civil society organizations started collaborating towards a new law, in response to the disappointment about Law no. 32/2004 and GR no. 72/2005 and the reluctance of the government to take the initiative. ${ }^{45}$ In the end, six distinct policy communities involved in this process can be distinguished. They "translated" their larger policy goals into concrete demands and proposals for articles to be included into the new law, which were then eventually championed by different MPs involved in the debates about the Village Law Bill in the Special Committee. We will discuss these objectives one by one, loosely following the stages of the law-making process.

\subsubsection{Better Position for Village Heads}

The issues that started the law-making process had little to do with human rights or a public interest policy agenda. In July 2006, Parade (Persatuan Rakyat Desa, Association of Village People) Nusantara and associated organizations of village government officials held a discussion meeting in Semarang with several representatives from the national Parliament. ${ }^{46}$ They agreed that "the desa as the pillar of the Indonesian nation should be regulated decently and professionally." This meeting followed an earlier one between representatives of Parade and members of the Regional Representative Council (Dewan Perwakilan Daerah) ${ }^{47}$ on 3 April of the same year. At this occasion, the former lobbied the latter to promote the case for a new Village Law to Parliament. The event was accompanied by demonstrations involving thousands of village officials from mostly Central Java. This was only one in a series of demonstrations by village officials, which started in February 2006 and would be reiterated at strategic points in time up until the law was taken to Parliament in 2012. ${ }^{48}$ These actions were key in taking the issue of a new Village Law to the national level. ${ }^{49}$

44. Merry (2006), pp. 38-51; Merry (2009).

45. See for the criticism Zakaria (2000), Chapter 8: "Epilog: Kebijakan Baru, Tantangan Baru"; Rozaki \& Rinandari (2004); and Eko \& Krisdyatmiko (2006).

46. Interview with Suryokoco Suryoputro on 17 September 2015 in Jakarta. Suryoputro was the general secretary of Parade Nusantara at the time of the actions in 2006 and the coordinator of the federation-like association Supporters of Village Empowerment in the Archipelago (Relawan Pemberdayaan Desa Nusantara).

47. The DPD represents regional interests at the national level and together with Parliament constitutes the People's Constituent Assembly (Majelis Permusyaaratan Rakyat), which holds the power to amend the Constitution.

48. Footage of the first demonstration on 7-8 February 2006 is available on YouTube (2017).

49. Personal communication Suryokoco Suryoputro to Yando Zakaria (13 April 2007). 
Yet, it needed more than Parade Nusantara to finally get the government and Parliament to take action. Only in mid-2007 did the minister of home affairs officially decide that a village law should be drafted. He acted in direct response to a ruling by the Constitutional Court which ordered the revision of the direct election of regional heads. ${ }^{50}$ The government then decided that it would replace the Regional Autonomy Law no. 32/2004 by three separate statutes: one on regional government, one on the election of regional heads, and one on village government. Within the Ministry of Home Affairs, the Directorate General of Village Government and Society moreover provided an entry point for lobbyists from Parade Nusantara and other policy communities supporting the law (see below).

In summary, it was a combination of external pressure from Parade Nusantara and internal state processes pushed by the Constitutional Court that started the law-making process. The items on the agenda of Parade Nusantara included the demand that village government officials could become members of a political party, that their office term would be extended, and that they would obtain the status of civil servant (PNS). Internally, the organization was divided between those who struggled for more village autonomy in general and others who were mainly interested in increasing their power and remuneration. Thus, the first steps towards the next Village Law were informed as much by private as by public interest concerns.

\subsubsection{Acknowledgement of Diversity in Community Governance and Institutions}

The first concrete step in the actual law-making process was the preparing of the so-called Academic Document (Naskah Akademik). The Ministry of Home Affairs' Directorate of Village Communities and Government invited CSOs and development donor institutions to provide input to this process. This was the perfect opportunity for activists and academics to promote the issues they thought were important for a new village law. Coming from many different organizations, ${ }^{51}$ they established a network called the Forum for Renewing and Empowering the Village (Forum Pembaruan dan Pemerdayaan Desa) to exchange views and work more effectively towards incorporating their objectives into the law. ${ }^{52}$ At the top of this policy community's list was the acknowledgement of diversity in village governance and institutions - a point they had been pushing for since 1998. Their effort found legal support in Article 18B(1) and (2) of the Constitution, which stipulate that "The State shall recognize and respect entities of regional administration that possess a specificity or a distinctiveness that are to be regulated by law" and "The State shall recognise and respect, to be regulated by law, the homogeneity of societies with customary law along with their traditional rights for as long as they remain in existence and in agreement with societal development and with the principle of the Unitary State of the Republic of Indonesia." The acknowledgement of such diversity indeed became part of the Academic Document, a 100-page document that was finalized in July 2007.

50. 5/PUU-V/2007.

51. Among others, the Institute for Research and Empowerment Yogya, Formasi Kebumen, and Circle for Village and Agrarian Change (Lingkar Pembaharuan Desa dan Agraria (Karsa)). Prominent figures included Sutoro Eko, Ari Sujito, and Ari Dwipayana.

52. Yando Zakarian was a member of this network on behalf of the non-governmental organization (NGO) KARSA. 


\subsubsection{Power, Land, and Money to the People}

The Academic Document was submitted to public consultation in several regions, and the government on this basis started preparing a Bill, in a process that was as closed as the previous one had been transparent. Progress was very slow, mainly because of resistance from key bureaus within the Ministry of Home Affairs itself, which did not like changes in the current situation for three reasons. First, the increase in village autonomy would mean a decrease in the power of the higher levels of government - that is, their power would be circumscribed. Second, the budget for the envisaged increase in village funds would be financed from budget cuts of village-level programmes that they administered. This would mean, for example, that public works/infrastructure services at the district level would receive smaller budgets than before, and that they could no longer decide which contractors should implement the projects in villages. This would lead to a serious loss of opportunities to earn extra income connected to meetings, supervision of projects, etc. ${ }^{53}$ Third, the implementation of the Village Law would be an administrative steeple chase, as it involved several ministries whose policies and regulations needed to be harmonized.

In response to the stalling of the process, the policy community around village diversity together with members of the Regional Representative Council (DPD) ${ }^{54}$ with whom they had personal connections tried to work around the government and started to draft their own Bill based on the Academic Document. In this manner, pressure was put on the government to come forward with its Bill, since otherwise Parliament might be convinced by the DPD and their allies to use its right of initiative instead. ${ }^{55}$ Although eventually the legislative process proceeded with the government draft, this strategy worked as an effective means of putting pressure on the government. A key role in this process was played by former activist and current MP, Budiman Sudjatmiko.

Sudjatmiko had been a prominent activist during the New Order when he campaigned for land reform and the rights of the people in rural areas. This made him easily accessible for activist-academics from all the policy communities involved. His involvement in the 1996 protests against the New Order landed him in jail to serve a 13 -year sentence, ${ }^{56}$ but it also gained him the support of the then PDI-chair Megawati Soekarnoputri and, in 1998, Sudjatmiko was released. In 2009, he was elected to Parliament for the Indonesian Democratic Party of Struggle (PDI-P), with the support of the village diversity policy community and with village reform as his major focus. In his memoirs, Sudjatmiko recalls how, in 2005, he first developed the idea to use the village as a vehicle for promoting land rights and promoting equality, and it was this idea that he could pursue by promoting the Village Law. ${ }^{57}$

Around this objective, another policy community formed that campaigned for increasing the autonomy of villages, so that they could better resist encroachment of village land. The village was to become a legal subject with recognized rights. A second objective was to reinforce village power by allocating more money to the village budgets, which was

53. Tidey (2012), p. 150. Of course projects also open up opportunities for corruption; this may also have played a role.

54. This council represents the regions at the national level (see Arts. $22 \mathrm{C}$ and $22 \mathrm{D}$ of the Constitution).

55. In the end, this Bill never obtained an official status, but it became part of the documents the government later submitted to Parliament.

56. Sukma (1998), pp. 105-23.

57. Sudjatmiko (2014), pp. 247-55. 
supposed to lead to a more equal distribution of wealth. The rallying slogan became that $10 \%$ of the national budget should go to the villages. ${ }^{58}$

Where it concerned the Village Law, Sudjatmiko turned out to be an effective political operator. In 2010, he succeeded in getting his party behind the effort to have the Village Law included into that year's Prolegnas. He moreover got an official position as adviser (Pembina Utama) of Parade Nusantara. ${ }^{59}$ Supported by Parade Nusantara demonstrations, ${ }^{60}$ he managed to have Parliamentary Commission II push the Yudhoyono government to finally submit its Bill to Parliament, threatening that otherwise Parliament would take the initiative and create its own draft. ${ }^{61}$ In the end, the government gave in and submitted its Bill to Parliament. In almost all respects, the result was completely different from the suggestions made in the Academic Document and tried to maintain the status quo. Parliament then established a Special Committee (Panitia Khusus) for debating the draft. ${ }^{62}$ Representing the PDI-P, Sudjatmiko became one of its deputy-chairmen. Sudjatmiko moreover managed to have three activist-academics appointed to the Expert Staff of the Commission. These would provide a crucial point of access for input from all policy communities involved. And, finally, the old network called the Forum for Renewing and Empowering the Village (Forum Pembaruan dan Pemerdayaan Desa), now under the new name of the Circle for Village and Agrarian Renewal (Lingkar Pembaruan Desa dan Agraria), received the opportunity to present a working paper to the Special Committee (on 20 June 2012). Its contents were almost the same as those of the Academic Document made five years earlier.

\subsubsection{Recognition of Customary Communities and Their Land Rights}

Before we continue with a brief analysis of the debates in the Special Committee, we will first discuss the three other policy communities that were involved in the process. The first of these was concerned with the recognition of customary communities and their land rights. With the National Association of Indigenous Communities (AMAN) at its centre, this community was ambiguous about a new village law, as such a law could only provide partial support for their cause. They preferred a law that dealt specifically with customary communities. In 2011, before the legislative process of the Village Law was resumed, AMAN created a first draft for a new law on the Recognition and Protection of Indigenous Communities Rights. ${ }^{63}$ A revised draft was published in 2013. ${ }^{64}$ However, AMAN and its allies changed their policy when they found out that they could not manage to get such a Bill included in the Prolegnas, because of the resistance of companies exploiting the areas that the new draft would recognize as customary lands. Recognizing that an option in the new law to establish so-called desa adat could be a positive step towards recognition of customary communities, they decided in a pragmatic fashion to support the Village Law as a second-best option-even if adat land rights often

58. Later in the drafting process, this was limited to $10 \%$ of the regional transfer budget; see Kompas.com (2014).

59. The good relations between Sudjatmiko and Parade Nusantara did not last when the organization decided to support Prabowo Subianto as presidential candidate against PDI-P's Joko Widodo. Erik (2014).

60. Ferdinand (2012).

61. Iradio (2011).

62. Later on, much of the work was carried out by a smaller committee selected from the Special Committee, the so-called Working Committee (Panitia Kerja).

63. Rancangan Undang-Undang Tentang Pengakuan dan Perlindungan Hak-Hak Masyarakat Adat; see Aman.or.id (2014).

64. Hukumonline.com (2013). 
stretched beyond the boundaries of a single village. ${ }^{65}$ The policy community around AMAN did little to actively support the passing of the Village Law, but it was important that they did not oppose the law-making process. Their attitude was moreover important for those who promoted diversity in villages, including the option for the recognition of Adat villages.

\subsubsection{Better Democratic Control}

A fifth policy community saw a village law as a means for facilitating better democratic control of government institutions and their budgets. ${ }^{66}$ This "democracy" policy community consisted of critical but idealistic CSOs, many of which receive financial support from foreign donor institutions. It also included academics who work occasionally as consultants and advisers for the government or for international development organizations. Their view of village societies contrasts sharply with the one held by the policy community focusing on customary communities: they see villages as heterogeneous entities, containing different interest groups and socioeconomic classes. ${ }^{67}$ Moreover, they sometimes also found themselves at loggerheads with the community around Parade Nusantara, which was not much in favour of control on the village administration. One member of this policy community, Sutoro Eko, was included into the expert team to support the drafting committee, which secured important input throughout the process.

\subsubsection{Community Driven Development}

The sixth policy community comprised the international donor institutions that have been actively promoting decentralization since 1998. Most important among these is the World Bank. Inspired by the idea that stronger social capital will foster development, ${ }^{68}$ the World Bank started community-driven development (CDD) and social fund approaches during the 1990s. ${ }^{69}$ These aim at interventions that more effectively supported community development and local accountability mechanisms. In 1998, the World Bank commenced the already mentioned Kecamatan Development Program, which, in 2007, was replaced with the National Program for Community Empowerment (PNPM Mandiri). PNPM focuses on reducing poverty in all Indonesian provinces through a community planning process that invests in small-scale infrastructure projects for individual villages and urban wards, and which generates employment. $^{70}$

For the World Bank and its allies, a new village law was attractive because it had the potential to consolidate the PNPM programme. The World Bank and other international donor institutions supported activities of CSOs mentioned above and facilitated public consultations as part of their ongoing support for democratization. Meanwhile, their staff remained in close contact with government officials for whom they acted as advisers. The experiences with the PNPM and other village-level programmes also led to concern on their

65. In the wake of the 2014 Village Law, a Regulation of the Minister of Agrarian Affairs (Permendagri No. 52 Tahun 2014 tentang Pedoman Pengakuan dan Perlindungan Masyarakat Hukum Adat) created new options for recognition, be it at a lower legal level than a full Law. Sopian (2014).

66. Eko, supra note 4.

67. AKATIGA, supra note 26. See more at http://www.ireyogya.org (accessed 25 August 2017).

68. Bebbington (2006), pp. 1958-76; Bebbington et al. (2006).

69. McCarthy et al., supra note 26.

70. Worldbank.org (2014). 
part about the implementation of the new law and its effects. They were therefore keen on having sufficient supervisory mechanisms introduced into the law, to make sure that no abuse was made of these funds. ${ }^{71}$

\subsection{The Debates in the Special Committee and the Working Committee}

After the Special Committee had been formed, the law-making process then continued with the drafting and debate of the so-called Inventory of Problems (Daftar Inventarisasi Masalah). In this document, the political parties in Parliament table the main issues they wished to discuss. The Inventory was quite extensive, for it included all the issues that were championed by the six policy communities mentioned. All six had managed to convince party members involved in the debate to promote their cause. The debates were a mix of legal and political arguments, with the government generally giving in to the positions championed by the MPs concerned. An example is the provision about the position of villages, which, in the government Bill, was "under the regional government." It was changed into "villages are located in the area (wilayah) of a District/City," with the main argument that Article 18B of the Constitution grants them a degree of autonomy. That it was not easy to reach this result is witnessed by the fact that the discussion took five to seven meetings within two months. On the issue of the types of village that should be allowed, the government and Parliament agreed to recognize "normal" and adat villages, instead of the three types of villages that the first policy community proposed.

What all parties and the government agreed about was that the villages should be allocated independent funds. The debate was mostly about where this money should come from. With the government resisting the idea to have this money directly allocated from the regional or national budget, a way out was found by deciding that these funds could be gathered from all the separate projects that were carried out at the village level. The question then became how much money should be allocated. The Gerindra MP proposed to just allocate IDR 1 billion (approximately EUR 800,000) to each village, irrespective of its size and number of inhabitants. The committee then charged a research institute to assess the amount of money that was allocated to villages in Central Java. The result was that about $10 \%$ of the national budget was spent at village level anyway in this form and this became the guiding percentage in the discussions. The government, represented by the minister of home affairs, and supported by the president's Partai Demokrat, continued to resist including such a number in the law. In the end, it required three consultative meetings with the leadership of Parliament, the minister of home affairs, and the minister of finance before the matter could be settled.

Serious debate concerned the length of the term of office of village heads and how often a village head could be re-elected, one of the major concerns for the Parade Nusantara policy community. Proposals ranged from five to ten years, and no party proposed the same. An important argument by those who promoted a long term of office was that village head elections caused so much turmoil that, in order for villages to remain relatively stable, such elections should be held as seldom as possible. In the end, all the parties agreed to a compromise that was in the middle of all proposals: six years with the possibility to be re-elected thrice.

71. This information comes from the conversations Zakaria had with World Bank staff during consultancies he did for them. 
Only the cause championed by the policy community around indigenous rights failed to get recognition of communal land of adat villages in the Village Law. This had to do with the difficult position of the Ministry of Home Affairs vis-à-vis the Ministry of Forestry and the National Land Agency, where it failed to convince these that they should accept such regulation.

It is beyond this article to go deeper into these debates, but these above are useful illustrations to get an idea of the process. If we look at them, it is striking how serious they were and how much substance mattered. Legal arguments played a considerable part, as did issues of feasibility when it concerned finances, for instance. Another point is that all involved were willing to strike compromises - the government even to a degree that no one would have fathomed before the process started. This—we think — can only be explained by the political situation that this law was adopted at the end of the term of both President Yudhoyono and Parliament. All involved saw the attraction of being able to boast the promulgation of such an important law and to cement the support from the different policy communities involved. Indeed, after the law was passed, presidential candidate Prabowo Subianto tried to get the credit for the passing of the Village Law, where the key role was played by PDI-P's MP Sudjatmiko. This finding is in line with Stephen Sherlock's analysis of how the Indonesian Parliament, despite its elitist nature, is forced to take its voters seriously. ${ }^{72}$ On this basis, it may make surprisingly sensible decisions.

\section{RESULTS: THE 2014 VILLAGE LAW}

On 15 January 2014, the Village Bill was signed into law by President Susilo Bambang Yudhoyono as Law no. 6/2014. It introduced five major changes to the existing village regulation. First, the new option of choice between desa and desa adat accommodates the wish for variety in types of villages. Recognition as a desa adat means an important step towards recognition of customary land rights. The term desa adat is easily associated with traditional governance through the old adat institutions, which may go against human rights, ${ }^{73}$ but the law explicitly requires that desa adat operate in conformity with these (Articles 98(2) and 111(2)). Second, the village is no longer regarded as a unit under the district or subdistrict (kecamatan), but instead is an autonomous legal entity. Nonetheless, these government levels can use the strict rules on accountability regulation to control village budget spending, which means that, for many villages, autonomy is severely constrained. At the same time, the opportunities for these government levels to use mark-ups and other rentseeking opportunities are reduced by a third change: the Village Law combines assets and operating accounts meant for the village-level programmes into one national budget for village funding (dana desa). This means that - at least in theory-the implementation of the Village Law requires no additional budget. Fourth, the law provides for new planning and budgeting procedures. All projects must be included into the village five-year plans (RPJMdes) and into the yearly budget, including activities of external organizations as CSOs and companies. A fifth innovation is the village Parliament, the musyawarah desa. This is the highest body in village government. It curtails the power of the village head and can bring

72. Sherlock (2010), pp. 160-78.

73. Vel \& Bedner (2015), pp. 493-507. 
Table 1. The realization of the policy communities' goals in the 2014 Village Law

\begin{tabular}{|c|c|c|}
\hline Main goals & $\begin{array}{l}\text { Policy community's } \\
\text { main actors }{ }^{\mathrm{a}}\end{array}$ & $\begin{array}{l}\text { Achievement in } \\
\text { Law no. 6/2014 }\end{array}$ \\
\hline Stronger position village head & $\begin{array}{l}\text { Village Head Association, } \\
\text { Parade Nusantara }\end{array}$ & $\begin{array}{l}\text { Art. 33: lowered } \\
\text { requirements; } \\
\text { Art. 39: longer tenure } \\
\text { (max. } 3 \times 6 \text { years) }\end{array}$ \\
\hline $\begin{array}{l}\text { Diversity in villages and village } \\
\text { institutions } \\
\text { Recognition of customary communities }\end{array}$ & $\begin{array}{l}\text { KARSA, AMAN, HUMA, } \\
\text { Epistema }\end{array}$ & Section XIII: desa adat \\
\hline More money for the village budget & $\begin{array}{l}\text { FPPD, IRE, Village Head } \\
\text { Association }\end{array}$ & $\begin{array}{l}\text { Art. } 72 \text { : national } \\
\text { budget allocation for } \\
\text { villages }\end{array}$ \\
\hline $\begin{array}{l}\text { Better democratic control—village } \\
\text { autonomy and musyawarah desa } \\
\text { Agrarian reform }\end{array}$ & $\begin{array}{l}\text { FPPD, IRE, LAPPERA } \\
\text { KARSA, KPA. Bina Desa }\end{array}$ & $\begin{array}{l}\text { Art. } 19, \text { Art. } 54 \\
\text { Art. } 26-\mathrm{j}\end{array}$ \\
\hline $\begin{array}{l}\text { More efficient community-driven } \\
\text { development }\end{array}$ & $\begin{array}{l}\text { International donor } \\
\text { institutions and government }\end{array}$ & Section IX \\
\hline
\end{tabular}

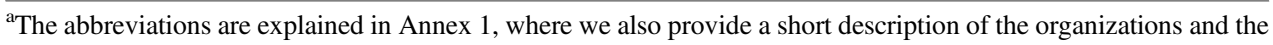
link to their website, if available.

a solution in cases where, under the previous situation, conflicts between the village consultative body (BPD) and the village head would lead to a stalemate.

The objectives of these policy communities can all be perceived in the final result of the legislative process, as indicated in Table 1. This table indicates how the policy communities described above have all succeeded to some extent in promoting their agenda through the new Village Law, even if some have been more successful than others. The World Bank, for instance, saw considerable digression from its original PNPM programme, as the control higher government bodies can exert over how village funds are being spent became increasingly larger.

Despite these successes, the final result indicates that the Village Law reflects a compromise that still requires many policy choices before particular objectives are effectively realized. This indeed became clear when the first implementing regulations were released and effected by the central government in the course of 2015, leading to frustration on the part of some of the policy communities mentioned.

\section{IMPLEMENTING THE NEW VILLAGE LAW}

The first disappointment for all the policy communities involved was that it took much longer than they had expected before the new Village Law started to be implemented. Enacted in January 2014, it took more than a year before any concrete results could be perceived. An obvious reason was that 2014 was a year of general elections-both parliamentary elections in April and presidential elections in July. As a consequence, the incumbent national cabinet had the status of "outgoing" until the formation of a new cabinet, with only a limited mandate. The newly elected President Joko Widodo presented his new cabinet on 26 October 2014, after three months of serious reshuffling with ministries and cabinet member candidates. 
Another reason for delay was the establishment of a Ministry of Villages as part of the new government. Although this was meant to make implementation easier, in practice, it led to bureaucratic battles between three ministries: Finance, Home Affairs and the new Villages Ministry. The main prize was the drafting of the Village Law's implementing legislation, which, given the framework character of the law, is of key importance to its eventual outcomes. The main issues were the distribution and transfer of funds between various levels of government, the management of village-owned business entities, the use of village funds, and the arrangements of accountability. Control of these processes provides advantages in terms of power and money.

\subsection{Bureaucratic Battles over Implementing Legislation}

In 2014, the Ministry of Home Affairs started designing implementing regulations on its own. Two directorates were in charge: the Directorate on Village Government and the Directorate for Village Development Activities. Until 2014, the bureaucratic culture in the Ministry of Home Affairs had been geared towards efficient top-down management of Indonesia's regional administration. Creating a diversity of village governance institutions and providing the desa with a large degree of autonomy — as the Village Law required — went flatly against this situation.

At the same time, the Ministry of Home Affairs put pressure on villages to choose for a status as desa or desa adat. It held onto the term of one year mentioned in Article 116(3) for villages to register as desa adat. In a swift move, the ministry moreover used its executive prerogative to draft GR no. 43/2014, which was issued in June. This regulation limited the autonomy of the desa to designate themselves as desa adat, by transferring this power to the district government (Article 37). It also introduced considerable limitations and conditions on spending the village funds. Key among them is the provision that village funds can only be used on the basis of the village's development plan. This plan needs to be approved by the district government after it has checked on consistency with the district development plan (Article 154).

The next GR (no. 60/2014) was prepared by the Ministry of Finance to regulate the administrative process concerning the village fund (dana desa). This regulation also put limitations on the autonomy of villages because of the many requirements in reporting that it introduced, and because it made village governments financially accountable via the district to the Ministry of Finance.

In October 2014, shortly after he took office, President Jokowi created the new Ministry of Villages, Disadvantaged Regions and Transmigration (henceforth, the Village Ministry). It was at least partly the fruit of intensive lobbying by CSOs, which through such a new ministry hoped to secure better access to the process of implementation. The new position of Village Minister went to the traditional-liberal Islamic PKB, while the Ministry of Home Affairs came into the hands of President Jokowi's PDI-P. However, the Ministry of Home Affairs remained involved in the Village Law implementation as well. It continued to promote hierarchical control over village affairs, as opposed to the Village Ministry, which supported the bottom up-approach that the CSO activists involved in making the law pursued.

In January 2015, the president issued a decree that divided the authority over villages between the two ministries. ${ }^{74}$ The Ministry of Home Affairs remains in charge of administrative matters and village government, including policies related to local civil

74. Ina (2015). 
servants and employment. Matters related to the planning of local development programmes, including the monitoring and the empowerment of rural communities, reside under the Village Ministry. Additionally, the Ministry of Finance holds the main authorities related to the village fund. Subsequently, each of these ministries has issued ministerial regulations, which have often led to confusion for district governments about which ones they were supposed to follow up with practical implementation. District governments explained the slow pace of their implementation activities on the absence of implementation guidelines from the Village Ministry as well as the lack of an instruction for technical guidance (BIMTEK) on how to handle the financial side of village management. In 2015, both GRs mentioned above were revised in a direction that pays more respect to village autonomy, but the confusing situation of three ministries in charge has remained. ${ }^{75}$

\subsection{Lack of Information and Capacity in Villages}

There were also reasons at the local village level why the implementation of the Village Law did not take off smoothly. First of all, there was a lack of information: many villagers did not even know it existed and-unsurprisingly-village government officials had difficulty in understanding the law's implications and requirements. Some village governments were cautious about spending the dana desa, because they feared being accused of corruption (as discussed in a report on dana desa by the Corruption Eradication Commission KPK) ${ }^{76}$ if anything would be lacking in the accountability reports. Second, there is a shortage of capacity at all tiers according to a report of the research body of the Village Ministry from December $2015 .^{77}$ It mentions that village budgets often arrive late because the regulations keep on changing; there is a lack of capacity in the village for making business plans and project proposals; there are problems with book keeping; there is a lack of facilities like electricity, computers, and Internet access; and there is a lack of capacity to operate communication equipment. Third, there is no assistance from village law "facilitators" yet, who are required to help the villages with the implementation process. Under these conditions, a market for professional services to village governments has emerged, in which (sub-)district government officials offer their report-writing services for a fee, after office hours. ${ }^{78}$ To counter this development, the Village Ministry has advised the government to simplify the procedures for planning and finances, such as by transferring dana desa twice instead of three times per year, which would reduce the number of reports accordingly. ${ }^{79}$

\subsection{Absence of the Policy Communities}

The policy communities that had engaged actively in making the Village Law disappeared from centre stage after the enactment of the law. They had achieved their primary advocacy goals and continued with other agendas. The activist members of Parliament shifted their attention to the next legislation process, in particular the revision of the agrarian law.

\footnotetext{
75. See Eko (2015).

76. See KPK (2015).

77. Balitlatfo (2015), p. 94.

78. Information from NGO field workers in Sumba, February and August 2016.

79. Balitlatfo, supra note 77.
} 
Initially, some CSOs of the democracy policy community engaged in the "socialization" of the Village Law in meetings all over the country to explain its content and opportunities. However, funding for these activities gradually ran out, when international donor organizations shifted their focus from support for CSO advocacy to capacity-building and technical advice for government institutions that are crucial for the implementation of the law. ${ }^{80}$

The result is that the eventual realization of the policy goals of the policy communities involved in the drafting of the Village Law is now almost completely dependent upon the same bureaucracy they bypassed earlier in the drafting process.

\section{CONCLUSION}

What are the lessons we can learn from the making of the Village Law in Indonesia? How does (participation in) making a new law help to change pre-existing dynamics of power to arrive at new outcomes?

The genesis of the 2014 Village Law confirms that the law-making procedure in Indonesia offers several opportunities for policy communities outside the government and the Parliament to influence the process and its outcomes. To turn an idea into a Bill and a Bill into a law requires quite distinct steps, from getting one's item into the Prolegnas, via the Academic Document, to the actual Bill and the debates in Parliament. Of particular interest in this case is the split between government drafts and Parliament drafts. When the government halted the process, policy communities together with an activist-turned-MP forced the government into resuming it by threatening to have Parliament take over the initiative and thus outmanoeuvred the government. Due to sustained pressure, lobbying and direct influence policy communities succeeded in forcing the government to accept a law that was completely different from the draft the government presented at the start of the debates in Parliament. Although the president could have used a veto, in the end, he chose to boost his legitimacy by presenting the new Village Law as a government product-whereas in fact it were the policy communities involved that pushed the process through demonstrations, legal debate, political campaigns during the elections for the national Parliament, and active lobbying, sponsored by international donor organizations. An important explanation for their success is that the law lent itself to unite a diversity of policy agendas and the communities pushing them. This was partly a matter of chance. It is questionable whether the indigenous rights movement would have supported the Bill if they had been allowed to promote their "own" Bill.

The main problem registered is that most policy communities lost interest once the Bill had been passed. This may have been caused by the fact that, with the exception of the village head association, not a single one of them saw the law as "its own," but rather as a partial realization of their agenda. This is a particular problem in the case of the framework laws that are common in Indonesia. The Village Law is no exception in that it is unclear on several points and requires many implementing regulations. That puts the ball back into the government's court and the first results indicate that the government is not overly enthusiastic about trying to realize the goals mentioned above.

This indicates once again that law-making as a strategy to accomplish sociopolitical change does not end with the acceptance of the Bill by government and Parliament and the

80. See e.g. the Australian government-funded programme KOMPAK; see Kompak.or.id (2017). 
promulgation of the law. The policy communities acted as important intermediaries in the initial stages of the vernacularization process that translated democratization ideals and human rights into a national law aimed at increasing the welfare of the people living in Indonesia's nearly 75,000 villages. However, this process has not been completed. In addition to (1) the selection of a universal ideal or right as campaign goal, (2) legal mobilization in policy communities, and (3) participating in the legal drafting process, at least three more steps are required.

First, a negotiation process is needed with and within the executive branch of government on how implementation will take place. This includes not only creating clarity about authorities and drafting implementation, but also finding an answer to the reality of "practical norms" in the bureaucracy. Those norms refer to the informal rules of the game that reflect dynamics of power, at the national, district, and village levels of government. Second is translating the content of the law to local situations, and its implementation. That includes assistance to village citizens on how they can make use of the opportunities that this Village Law provides for them. The enormous task is put into the hands of Village Law facilitators, whom the Village Ministry has recruited mainly from the legion of people who had been previously employed in the rural PNPM programme as facilitators for explaining the procedures of that programme and supervising village projects. However, they have never been trained as intermediaries in the process of advocating villagers' rights. Third, in order to be able to change power relations at the village level, the new law should be complemented with a complaint mechanism and sanctions. Currently, it seems the only sanction available is that, when village governments fail in producing approved reports, the next disbursement of the Village Fund will be cancelled. There is no mechanism yet for complaints or sanctions in cases where powerful village elites benefit from the law's opportunities at the expense of marginalized groups.

It is too early to judge whether ultimately the Village Law will achieve the goals the policy communities involved in its genesis aimed to realize. It is clear, however, that, if this is to happen, it will be a long process that requires their continued involvement.

\section{REFERENCES}

AKATIGA (2010) Marginalized Groups in PNPM Rural, Bandung: AKATIGA—Centre for Social Analysis.

Aman.or.id (2014) "Draft RUU PPHMA versi AMAN, Agustus 2014," http://www.aman.or.id/ wp-content/uploads/2016/02/DRAFT-RUUPPHMA.pdf (accessed 16 August 2017).

Anggono, Bayu Dwi (2014) Perkembangan Pembentukan Undang-Undang Di Indonesia, Jakarta: Konstitusi Press.

Antlöv, Hans, Anna Wetterberg, \& Leni Dharmawan (2016) "Village Governance, Community Life, and the 2014 Village Law in Indonesia." 52 Bulletin of Indonesian Economic Studies $161-83$.

Arnscheidt, Julia (2009) "Debating" Nature Conservation: Policy, Law and Practice in Indonesia: a Discourse Analysis of History and Present, Leiden: Leiden University Press.

Aspinall, Edward, \& Mada Sukmajati (2016) Electoral Dynamics in Indonesia: Money Politics, Patronage and Clientelism at the Grassroots, Singapore: NUS Press.

Aubert, Vilhelm (1967) "Some Social Functions of Legislation." 10 Acta Sociologica 98-120.

Bagchus, René (1996) Waardevolle Instrumenten: de Totstandkoming van Beleidsinstrumenten Als Plicht, Ritueel en Zoektocht naar Legitimiteit, Delft: Eburon. 
Balitlatfo (Research and Development Institute of the Indonesian Ministry of Villages, Disadvantaged Regions and Transmigration) (2015) Dana Desa: Problematika dan Kontribusi, Jakarta: Ministry of Villages, Disadvantaged Regions and Transmigration.

Bebbington, Anthony (2006) "Local Capacity, Village Governance, and the Political Economy of Rural Development in Indonesia." 34 World Development 1958-76.

Bebbington, Anthony, Michael Woolcock, Scott Guggenheim, \& Elizabeth Olson (2006) The Search for Empowerment: Social Capital as Idea and Practice at the World Bank, Bloomfield: Kumarian Press.

Bedner, Adriaan (2001) Administrative Courts in Indonesia: A Socio-Legal Study, The Hague: Kluwer Law International.

Bedner, Adriaan (2008) "Amalgamating Environmental Law in Indonesia," in J. Arnscheidt, B. van Rooij \& J.M. Otto, eds., Lawmaking for Development: Explorations into the Theory and Practice of International Legislative Projects, Leiden: Leiden University Press, 171-98.

Bedner, Adriaan \& Stijn van Huis (2008) "The Return of the Native in Indonesian Law: Indigenous Communities in Indonesian Legislation." 164 Bijdragen tot de taal-, land-en volkenkunde/Journal of the Humanities and Social Sciences of Southeast Asia 165-93.

Breman, Jan (1982) "The Village on Java and the Early Colonial State." 9 Journal of Peasant Studies 189-240.

Datta, Ajoy, Harry Jones, Vita Febriany, Dan Harris, Rika Kumala Dewi, Leni Wild, \& John Young (2011) The Political Economy of Policy-Making in Indonesia, London: Overseas Development Institute.

Diani, Mario (1992) “The Concept of Social Movement." 40 The Sociological Review 1-25.

Eko, Sutoro (2014) Desa Membangun Indonesia, Yogyakarta: FPPD.

Eko, Sutoro (2015) "UU Desa: Layu Sebelum Berkembang?" Presentation, available at http://www. academia.edu/10401180/UU_Desa_Layu_Sebelum_Berkembang (accessed 25 August 2017).

Eko, Sutoro, \& Krisdyatmiko, eds. (2006) Kaya Proyek, Miskin Kebijakan: Membongkar Kegagalan Pembangunan Desa, Yogyakarta: IRE \& TIFA Foundation.

Erb, Maribeth, Priyambudi Sulistiyanto, \& Carole Faucher (2013) Regionalism in Post-Suharto Indonesia, London and New York: Routledge Curzon.

Erik, Purnama Putra (2014) "Parade Nusantara Bela Prabowo, Critic Budiman Sudjatmiko," Republika Online, 24 June, http://nasional.republika.co.id/berita/nasional/umum/14/06/24/n7n2ch-paradenusantara-bela-prabowo-kritik-budiman-sudjatmiko (accessed 22 June 2017).

Ferdinand, Waskita (2012) "Home Affairs Affirmed Struggle for Village Bill," Tribunnews.com, 14 December, http://www.tribunnews.com/nasional/2012/12/14/mendagri-tegaskan-perjuangkanruu-desa (accessed 22 June 2017).

Gibson, Christopher, \& Michael Woolcock (2005) "Empowerment and Local Level Conflict Mediation in Indonesia: A Comparative Analysis of Concepts, Measures, and Project Efficacy." World Bank Policy Research Working Papers 3713, https://doi.org/10.1596/1813-9450-3713 (last accessed 20 June 2017).

Hadiz, Vedi R. (2004) "Decentralization and Democracy in Indonesia: A Critique of Neo-Institutionalist Perspectives." 35 Development and Change 697-718.

Hesseling, Gertie (2009) "Land Reform in Senegal: L'Histoire se Répète? Legalising Land Rights: Local Practices, State Responses and Tenure Security in Africa, Asia and Latin America," in J. Ubink, A. Hoekema \& W. Assies, eds., Law, Governance and Development Research, Leiden: Leiden University Press, 243-70.

Holtzappel, Coen, \& Martin Ramstedt, eds. (2009) Decentralization and Regional Autonomy in Indonesia: Implementation and Challenges, Singapore: Institute of Southeast Asian Studies.

Hukumonline.com (2013) http://www.hukumonline.com/pusatdata/download/lt529722cc66c86/node/ 1t529722587e964 (accessed 22 June 2017).

Ina, Parlina (2015) "Authority Over Villages Split between Two Ministries," The Jakarta Post, 14 January, http://www.thejakartapost.com/news/2015/01/14/authority-over-villages-split-betweentwo-ministries.html (accessed 22 June 2017). 
Iradio (2011) "Hundreds of Village Chief Go to DPR Demands Discussion on Village Bill," Iradio, 12 May, http://iradiofm.com/ratusan-kepala-desa-datangi-dpr-tuntut-pembahasan-ruu-desa/ (accessed 22 June 2017).

Kompak.or.id (2017) "About KOMPAK, the GoI-GoA Partnership," http://kompak.or.id/en/page/ about/kompak-at-a-glance (accessed 16 August 2017).

Kompas.com (2014) "Penjelasan Budiman soal Proses RUU Desa yang Diklaim Prabowo," http://nasional.kompas.com/read/2014/06/17/1003309/Penjelasan.Budiman.soal.Proses.RUU.Desa. yang.Diklaim.Prabowo (accessed 16 August 2017).

Komisi Pemberantasan Korupsi (KPK) (2015) Laporan Kajian Sistem Pengelolaan Keuangan Desa, KPK: Jakartahttps://drive.google.com/file/d/0B_WVt_d0GR6TVW5aZWxIZXpMT3c/view (accessed 16 August 2017).

Lucas, Anton, \& Carol Warren (2013) Land for the People: The State and Agrarian Conflict in Indonesia, Ohio: Ohio University Press/Swallow Press.

McCarthy, John F. (2011) "The Limits of Legality: State, Governance and Resource Control in Indonesia," http://dx.doi.org/10.2139/ssrn.2281591 (accessed 20 June 2017).

McCarthy, John F., Dirk Steenbergen, Gregory Acciaioli, Geoff Baker, Anton Lucas, Vivianti Rambe, \& Carol Warren (2014) Dilemmas of Participation: The National Community Empowerment Program: Regional Dynamics in a Decentralized Indonesia, Pasir Panjang, Singapore: Singapore Institute of Southeast Asian Studies.

Merry, Sally Engle (2006) "Transnational Human Rights and Local Activism: Mapping the Middle." 108 American Anthropologist 38-51.

Merry, Sally Engle (2009) Human Rights and Gender Violence: Translating International Law into Local Justice, Chicago and London: University of Chicago Press.

Moore, Sally Falk (1973) "Law and Social Change: The Semi-Autonomous Social Field as an Appropriate Subject of Study." 7 Law \& Society Review 719-46.

Olivier de Sardan, Jean-Pierre (2011) "The Eight Modes of Local Governance in West Africa." 42 IDS Bulletin 22-31.

Olivier de Sardan, Jean-Pierre (2013) "The Bureaucratic Mode of Governance and Practical Norms in West Africa and Beyond," in M. Bouziane, C. Harders \& A. Hofmann, eds., Local Politics and Contemporary Transformations in the Arab World, Basingstoke: Palgrave McMillan, 43-64.

Purawan, Akhmad Adi (2014) "Review on the Establishment of Legislation in Indonesia." 26 Mimbar Hukum, Fakultas Hukum Universitas Gadjah Mada 534-45.

Riggs, Fred (1964) Administration in Developing Countries: The Theory of Prismatic Society, Boston: Houghton Mifflin.

Rosser, Andrew, \& Donni Edwin (2010) "The Politics of Corporate Social Responsibility in Indonesia." 23 The Pacific Review 1-22.

Rozaki, Abdur, \& Hesti Rinandari (2004) Memperkuat Kapasitas Desa dalam Membangun Otonomi: Naskah Akademik dan Legal Drafting, Yogyakarta: IRE Press.

Schulte Nordholt, Henk, \& Gerry van Klinken (2007) Renegotiating Boundaries: Local Politics in Post-Suharto Indonesia, Leiden: KITLV Press.

Sherlock, Stephen (2010) "The Parliament in Indonesia's Decade of Democracy: People's Forum or Chamber of Cronies," in E. Aspinall \& M. Mietzner, eds., Problems of Democratisation in Indonesia: Elections, Institutions and Society, Singapore: ISEAS, 160-78.

Soehendra, Djaka H. (2010) Sertifikat Tanah dan Orang Miskin: Pelaksanaan Proyek Ajudikasi di Kampung Rawa, Jakarta: KITLV-Jakarta/Leiden: Van Vollenhoven Institute.

Soemarno, Sumardjono Marsono, \& Dardjo Sumardjono (1980) Undang-undang Republik Indonesia Nomor 5 Tahun 1979 Tentang Pemerintahan Desa dan Proses Kelahirannya, Jakarta: Ministry of Home Affairs.

Soepomo, R. (1993) Bab-Bab Tentang Hukum Adat, Jakarta: Penerbit Pradnya Paramita.

Sopian, Hadi (2014) "Pengakuan Masyarakat Adat," kompasiana.com, 17 September, http://www. kompasiana.com/sopianhadi83/pengakuan-masyarakat-adat_54f5cf3ca333114a4f8b45b9 (accessed 22 June 2017).

Sudjatmiko, Budiman (2014) Anak-Anak Revolusi Buku II, Jakarta: Gramedia. 
Sukma, Rizal (1998) "Indonesia: A Year of Politics and Sadness." 1998 Southeast Asian Affairs $105-23$.

Tidey, Sylvia (2012) "Performing the State: Everyday Practices, Corruption and Reciprocity in Middle Indonesian Civil Service." PhD diss., Amsterdam Institute for Social Science Research (AISSR), University of Amsterdam.

Tømte, Aksel (2016) "The Role of NGOs as Facilitators - and the Politics of Implementation" Presented at New Law, New Villages? Changing Rural Indonesia: An International Workshop, Leiden University, 18-20 May 2016.

Trzcinski, Leah, \& Frank Upham (2014) "Creating Law from the Ground Up: Land Law in PostConflict Cambodia." 1 Asian Journal of Law and Society 55-77.

Ubink, Janine, André Hoekema, \& Willem Assies, eds. (2009) Legalising Land Rights: Local Practices, State Responses and Tenure Security in Africa, Asia and Latin America, Leiden: Leiden University Press.

Van Klink, Bart (2014) "Symboolwetgeving: De opkomst, Ondergang en Wederopstanding van een begrip." 29 Regelmaat 5-26.

Veerman, Gert-Jan (2015) "The Political Context of Law-Making," unpublished paper, on file with authors.

Veerman, Gert-Jan, \& Simone Hendriks-de Lange (2009) Over Wetgeving: Principes, Paradoxen en Praktische Beschouwingen, Den Haag: Sdu uitgevers.

Vel, Jacqueline, \& Adriaan Bedner (2015) "Decentralisation and Village Governance in Indonesia: The Return to the Nagari and the 2014 Village Law." 47 Journal of Legal Pluralism and Unofficial Law 493-507.

Vel, Jacqueline, John McCarthy, \& Zahari Zen (2016) "The Conflicted Nature of Food Security Policy: Balancing Rice, Sugar and Palm Oil in Indonesia." 26 Anthropological Forum 233-47.

von Benda-Beckmann, Franz, \& Keebet von Benda-Beckmann (2013) Political and Legal Transformations of an Indonesian Polity: The Nagari from Colonisation to Decentralisation, Cambridge: Cambridge University Press.

Voss, John (2008) Impact Evaluation of the Second Phase of the Kecamatan Development Program in Indonesia, Washington, DC: The World Bank.

Worldbank.org (2014) "Community Driven Development in Indonesia," http://www.worldbank.org/ en/country/indonesia/brief/community-driven-development-in-indonesia (accessed 22 June 2017).

Wright, Maurice (1988) "Policy Community, Policy Network and Comparative Industrial Policies." 36 Political Studies 593-612.

YouTube (2017) “Aksi Pertama Parade Nusantara," https://www.youtube.com/watch?v=gB_ ImGye9JI (accessed 22 June 2017).

Zakaria, R. Yando (2000) Abih Tandeh, Masyarakat Desa di Bawah Rejim Orde Baru, Jakarta: Lembaga Studi dan Advokasi Masyarakat.

Zakaria, R. Yando (2004) Merebut Negara: Beberapa Catatan Reflektif Tentang Upaya-upaya Pengakuan, Pengembalian, dan Pemulihan Otonomi desa, Yogyakarta: Lapera Pustaka Utama. 


\section{ANNEX 1: DESCRIPTION OF ORGANIZATIONS MENTIONED IN TABLE 1}

\section{Organization Description and website}

AKD Asosiasi Kepala Desa (Association of Village Heads), mostly regionally organized

AMAN Aliansi Masyarakat Adat Nusantara (Alliance of Indigenous People of the Achipelago), founded on 17 March 1999 in Jakarta (http://www.aman.or.id)

APDESI Asosiasi Perangkat Desa di Seluruh Indonesia (National Association of Village Government Officials in Indonesia) (https://id-id.facebook.com/ASOSIASIPERANGKAT-DESA-SELURUH-INDONESIA-APDESI-249969218014/)

Bina Desa Bina Desa (Village Empowerment) is an NGO for strengthening human resources in villages/village empowerment, founded on 20 June 1975 in Jatiluhur, Purwakarta, Jawa Barat (https://id.wikipedia.org/wiki/Bina_Desa)

Epistema Epistema Institute is a research and knowledge management centre on law, society, and the environment established by Epistema Foundation on 1 September 2010 in Jakarta (http://epistema.or.id/)

FPPD Forum Pengembangan Pembaruan Desa (Forum for Village Development and Reform) (http://www.forumdesa.org/index.php?pilih=news\&mod=yes\&aksi=lihat\&id=3)

HuMa Perkumpulan untuk Pembaharuan Hukum Berbasis Masyarakat dan Ekologis (Community and Ecological Based Society for Law Reform). (http://huma.or.id)

IRE Institute for Research and Empowerment. NGO with network of allied researchers in Yogyakarta, working on democratization and citizenship (http://www.ireyogya.org)

KARSA Lingkar Pembaruan Desa dan Agraria (Circle for Village and Agrarian Reform)

KPA Konsorsium Pembaruan Agraria (Agrarian Reform Consortium), based in all regions of Indonesia, founded on 24 September 1994 in Jakarta (http://www.kpa.or.id/news/ profile/)

LAPPERA Lembaga Penelian dan Pemberdayaan Rakyat (Institute for Research and People's Empowerment), Yogyakarta

Parade Persatuan Kepala Desa dan Aparat Desa Nusantara (Association of Village

Nusantara Government Apparatus of the Archipelago), in 2009 changed into: Persatuan Rakyat Desa Nusantara (Association of Villagers of the Archipelago) 